\title{
THE QUALITY OF DRINKING WATER AS A FACTOR IN THE FORMATION OF DENTAL PATHOLOGY OF THE HARD TISSUES OF THE TEETH IN CHILDREN
}

DOI: 10.36740/WLek202105113

\author{
Oksana V. Klitynska', Natalia V. Hasiuk ${ }^{2}$, Volodymyr I. Struk ${ }^{3}$, Roksolana Yu. Kruchak ${ }^{4}$, Viacheslav R. Gurando ${ }^{1}$, \\ Vasyl V. Bobelskyi ${ }^{1}$ \\ 1 UZHHOROD NATIONAL UNIVERSITY, UZHHOROD, UKRAINE \\ ${ }^{2}$ HORBACHEVSKY TERNOPIL STATE MEDICAL UNIVERSITY, TERNOPIL, UKRAINE \\ ${ }^{3}$ BUKOVINIAN STATE MEDICAL UNIVERSITY, CHERNIVTSI, UKRAINE \\ ${ }^{4}$ DANYLO HALYTSKY LVIV NATIONAL MEDICAL UNIVERSITY, LVIV, UKRAINE
}

\begin{abstract}
The aim: A study of the impact of drinking water quality on the state of dental health in schoolchildren who permanently live in areas of biogeochemical deficiency of fluorine and iodine.

Material and methods: The composition of the drinking water of the city of Uzhhorod and the city of Rakhiv has been investigated. The prevalence and intensity of dental caries in children is determined, drinking water is taken in accordance with Uzhhorod and Rakhiv.

Results: The regional features of the composition of drinking water of the mountain Rakhivsky district of the Transcarpathian region are the high variety of combinations of mineral components and the frequent excess of the normative content of dry residue components, namely nitrates, sulfates, chlorides, magnesium and calcium. Water oxidation, total stiffness and total alkalinity were significantly different. The established drinking water quality indicators have a direct dependence on the prevalence and intensity of dental caries in children, that is, a significant increase in the number of carious temporary, carious and distant permanent teeth and a decrease in filled temporary and permanent teeth $(\mathrm{p}<0.05)$ were diagnosed.

Conclusions: One of the most pressing problems in water hygiene is the urgent need to review and improve regulations, State sanitary regulations, standards and other regulations in the field of drinking water, including through the development of regional drinking water quality standards.
\end{abstract}

KEY WORDS: dental caries; temporary teeth, permanent teeth, intensity of caries, drinking water

Wiad Lek. 2021;74(5):1120-1124

\section{INTRODUCTION}

The role of drinking water in the formation and maintenance of children's health is proved by a large number of researchers and confirmed by practical doctors. $[1,2]$. The mineral composition of water, the content of harmful substances and microorganisms in it significantly affect the state of the bone system, muscles and the work of internal organs. That is, the quality of drinking water for daily consumption can both improve the state of health and worsen it.

That is, for the physiological formation of a healthy organism and maintaining its full functioning, it is necessary to consume high-quality drinking water daily. [3].

However, a large number of the world's population lives in geographically heterogeneous territories in which water resources do not meet standards. One of these territories is the Transcarpathian region, which is a natural zone of biogeochemical deficiency of fluorine and iodine, is an unfavorable background for the formation of a denture system in children permanently living in these territories and consume drinking water available for these territories $[4,5]$.

\section{THE AIM}

A study of the impact of drinking water quality on the state of dental health in schoolchildren who permanently live in areas of biogeochemical deficiency of fluorine and iodine.

\section{MATERIAL AND METHODS}

The studies carried out covered two geographical zones of the Transcarpathian region: the mountainous, in particular the city of Rakhiv and the lowland, Uzhhorod. The composition of drinking water and the state of dental health of schoolchildren in these cities were investigated.

Drinking water studies were carried out in the standardized laboratory of the "Transcarpathian Regional Laboratory Center of the Ministry of Health of Ukraine by order of the Committee on Hygienic Regulation of the Ministry of Health of Ukraine".

The quality of drinking water was determined according to microbiological standards of sanitary and chemical indicators in educational institutions of Uzhhorod city and Rakhiv city with centralized and decentralized water supply [6-10]. 
Table I. Analysis of drinking water of centralized water supply.

\begin{tabular}{|c|c|c|c|c|}
\hline $\begin{array}{c}\text { Source of research } \\
\text { Indicator }\end{array}$ & $\begin{array}{c}\text { Minaisky } \\
\text { water intake, } \\
\text { Uzhhorod }\end{array}$ & $\begin{array}{c}\text { Novodomaninsky } \\
\text { water intake, } \\
\text { Uzhhorod }\end{array}$ & $\begin{array}{l}\text { Rakhivsky } \\
\text { water utility }\end{array}$ & $\begin{array}{l}\text { Norm. Compliance with } \\
\text { State standard } \\
\text { specification (StSS) }\end{array}$ \\
\hline Scent & 0 & 0 & 16 & At $20^{\circ} \mathrm{C}$ \\
\hline Flavor & 0 & 0 & 0 & At $20^{\circ} \mathrm{C}$ \\
\hline Turbididy & $<1,0$ & $<1,0$ & $<1,0 \mathrm{HOK}$ & At $20^{\circ} \mathrm{C}$ \\
\hline Precipitate & - & - & - & \\
\hline Transparency & - & - & - & StSS 3351-74 \\
\hline Chromaticity & $<5^{\circ}$ & $<5^{\circ}$ & $<5^{\circ}$ & StSS 3351-74 \\
\hline $\mathrm{pH}$ & 7,4 & 7,6 & 7,9 & \\
\hline Chlorine is free, bound & - & - & - & $\mathrm{mg} / \mathrm{d}^{3} \mathrm{StSS} 18190-72$ \\
\hline Oxidation & 0,92 & 1,4 & 0,8 & $\mathrm{mg} \mathrm{O}_{2} / \mathrm{dm}$ \\
\hline Nitrogen in $\mathrm{mg} / \mathrm{l}$ & $<0,05$ & $<0,05$ & $<0,05$ & $\mathrm{mg} / \mathrm{d}^{3} \mathrm{StSS} 4192-82$ \\
\hline Nitrites & $<0,002$ & $<0,002$ & $<0,002$ & $\mathrm{mg} / \mathrm{d}^{3}$ StSS 4192-82 \\
\hline Nitrates & 15,8 & 5,8 & 7,4 & $\mathrm{mg} / \mathrm{d}^{3} \mathrm{StSS} 18826-73$ \\
\hline General hardness & 5,1 & 2.0 & 2,9 & mg-eq/dm ${ }^{3}$ StSS 4151-72 \\
\hline Dry residue & 108,0 & 80,0 & 120,0 & $\mathrm{mg} / \mathrm{d}^{3} \mathrm{StSS} 18164-72$ \\
\hline Chlorides & 31,0 & 16,0 & 10,0 & mg-eq/dm³stSS 4275-72 \\
\hline Sulfates & 20,1 & 8,2 & 14,7 & $\mathrm{mg} / \mathrm{d}^{3}$ StSS 4389-72 \\
\hline Iron & $<0,1$ & $<0,1$ & $<0,1$ & $\mathrm{mg} / \mathrm{d}^{3}$ StSS 4011-72 \\
\hline Copper & $<0,02$ & $<0,02$ & $<0,02$ & $\mathrm{mg} / \mathrm{d}^{3}$ StSS 4388-72 \\
\hline Zinc & $<0,1$ & $<0,1$ & $<0,1$ & $\mathrm{mg} / \mathrm{d}^{3} \mathrm{StSS} 18293-72$ \\
\hline Lead & $<0,01$ & $<0,01$ & $<0,01$ & $\mathrm{mg} / \mathrm{d}^{3} \mathrm{StSS} 18293-72$ \\
\hline Arsenic & $<0,01$ & $<0,01$ & $<0,01$ & $\mathrm{mg} / \mathrm{d}^{3} \mathrm{StSS} 4152-89$ \\
\hline Barium & - & - & - & $\mathrm{mg} / \mathrm{d}^{3}$ StSS 4192-82 \\
\hline Mercury & - & - & $<0,0005$ & $\begin{array}{c}\mathrm{mg} \text {-eq } / \mathrm{dm}^{3} \text { Sanitary rules and Norms (SanRN) } \\
\text { З83 від 23.12.96 }\end{array}$ \\
\hline Magnesium & 2,0 & 0,2 & 0,6 & mg-eq/dm³ SanRN 383 від 23.12.96 \\
\hline Manganese & $<0,01$ & $<0,01$ & $<0,01$ & $\mathrm{mg} / \mathrm{d}^{3}$ StSS 4974-72 \\
\hline General alkalinity & 1,1 & 1,1 & 3,0 & mg-eq/dm³ SanRN 383 від 23.12.96 \\
\hline Calcium & 3,1 & 1,8 & 2,3 & $\mathrm{mg}-\mathrm{eq} / \mathrm{dm}^{3}$ \\
\hline Fluorine & $<0,04$ & $<0,04$ & $<0,04$ & $\mathrm{mg} / \mathrm{dm}^{3}$ \\
\hline
\end{tabular}

Dental health was assessed by the prevalence and intensity of caries of temporary and permanent teeth in children of the appropriate age, for temporary bite -6 years, for permanent -12 years. [ 11].

The study was conducted at the Department of Pediatric Dentistry, Uzhgorod National University, Ukraine, and was approved by the ethics commission of Uzhgorod National University, which established compliance with general ethical rules for humane treatment of patients. when working with patients in accordance with the requirements of the Tokyo Declaration of the World Medical Association and the International Recommendations of the Helsinki Declaration of Human Rights.

Statistical analysis of the data was performed using methods of parametric and nonparametric statistics. Compliance empirical statistical distribution parameters of the theoretical Gaussian normal distribution was eval- uated using the Kolmogorov-Smirnov criterion (K.-S.) and Shapiro-Wilks (W), was an indicator of reliability [8].

\section{RESULTS}

According to the results, a reliable deterioration in the quality of drinking water according to microbiological indicators compared to 2016 year (296-22. 6\%; 200-20,9\%; p <0,05). In 2020, 371 samples did not meet the standards of 20 . $5 \%$, while in 2016 - 17. 7\% - 227 samples. In Rakhiv, the non-conformity rate was at the level of 55. 7\%, in Uzhhorod - $46 \%$. Most samples that do not meet the requirements of sanitary standards were recorded in institutions from decentralized water supply sources, but in 24 sources of natural water intake with a centralized water supply system, water samples did not meet the requirements for microbiological indicators (in 5 institutions of Uzhhorod, 1 in Rakhiv). 
Table II. Prevalence and intensity of caries of temporary and permanent teeth in children of different geographical zones of Transcarpathian region.

\begin{tabular}{|c|c|c|c|c|}
\hline \multirow{2}{*}{$\begin{array}{l}\text { Contingent } \\
\text { Age groups }\end{array}$} & \multicolumn{2}{|c|}{ Residents of Uzhhorod ( $n=1161$ ) } & \multicolumn{2}{|c|}{ Residents of Rakhiv ( $n=250$ ) } \\
\hline & Prevalence of caries, $\%$ & $\begin{array}{c}\text { Intensity of caries, } \\
\text { conventional units(cu) }\end{array}$ & Prevalence of caries, \% & Intensity of caries, cu \\
\hline $\begin{array}{c}\text { 5-6 years } \\
\text { temporary teeth (CFE) }\end{array}$ & $95,3 \pm 1,7$ & $12,9 \pm 0,2$ & $98,3 \pm 2,2$ & $14,9 \pm 0,6$ \\
\hline $\begin{array}{c}12 \text { years } \\
\text { permanent teeth (CFE) }\end{array}$ & $87,4 \pm 1,3$ & $10,9 \pm 0,1$ & $91,4 \pm 2,3$ & $12,3 \pm 1,2$ \\
\hline
\end{tabular}

Table III. Structure of caries intensity indices of temporary and permanent teeth in children of different geographical zones of Transcarpathian region.

\begin{tabular}{cccccc}
\hline \multirow{2}{*}{ Indicators } & \multicolumn{4}{c}{ Intensity of caries, cu } \\
\cline { 2 - 6 } Contingent & \multicolumn{2}{c}{ Temporary teeth, cf } & \multicolumn{2}{c}{ Permanent teeth, CFE } \\
\cline { 2 - 6 } & $\mathbf{C}$ & $\mathbf{f}$ & $\mathbf{C}$ & $\mathbf{F}$ & $\mathbf{2}$ \\
\hline Residents of Uzhhorod & $5,4 \pm 0,1$ & $7,5 \pm 0,2$ & $2,3 \pm 0,1$ & $5,4 \pm 0,2$ & $0,2 \pm 0,1$ \\
\hline Residents of Rakhiv & $10,1 \pm 0,1^{*}$ & $4,8 \pm 0,1^{*}$ & $5,6 \pm 1,2^{*}$ & $5,8 \pm 1,2^{*}$ \\
\hline
\end{tabular}

Note: ${ }^{*} p<0.05$ reliability with indicators of Uzhgorod residents.

The average rate of non-standard samples in institutions with centralized water supply is $7.3 \%$ (in $2016-9.4 \%$ ), namely, in Rakhiv (37.5\%) and Uzhhorod (9.5\%). As for the quality of drinking water in institutions with decentralized water supply, deviations from the standards were found in 25. 3\% of institutions (in 2016 - in $16.7 \%$ of sources of natural water intake), where laboratory water studies were carried out, the average indicator in the region of unsatisfied samples is 214 (in $2016-15.6 \%$ ).

Studies of drinking water according to sanitary and chemical indicators of 2020 found deviations from the norms in 73 institutions, which is 9\% (in 2016 - 11.9\%). 1091 samples did not meet the standards of 80 (7.3\%) samples. Higher than the average of this indicator in the region in Uzhgorod institutions (42.9\%), compared with Rakhiv institutions (17\%).

Water samples taken from GPZ, which are located on centralized water supply sources, did not meet the requirements for sanitary and chemical indicators: 4 in g. Uzhhorod and in 2 in d. Rakhiv.

Studies to determine the content of pesticides in drinking water samples were carried out by 3 sanitary and hygienic laboratories (regional laboratory center and 2 of its branches). 155 drinking water samples were examined during the year, which in all indicators corresponded to Sanitary Rules and Norms (SanRN) 2.2.4-171-10 "Hygienic requirements for drinking water intended for human consumption".

The total number of samples examined for the content of residual amounts of pesticides in 2017 was 426 (food raw materials and drinking food -139 , drinking water -155 , water in open ponds -59 , soil -73 . If the volume of research on environmental objects varies slightly over the past 4 years, then research on food products decreases annually: compared to $2016-1.9$ times, since $2015-2.7$ times, and since 2014 -7.8 times. All tested pesticide residue control facilities met hygienic standards (SanRN 8. 8. 1. 2. 3.4-000-2001) ( Table I).

A study of the prevalence and intensity of caries of temporary and permanent teeth is given in Table II. (CFE-Caries, Filling, Extracted), cu-Conventional Unit) ( Table II).
Distribution of caries intensity indices cf (caries, filling) and CFE(Caries, Filling, Extracted) are given in Table III.

\section{DISCUSSION}

The quality of drinking water consumed by residents is a significant factor in preventing disease and belongs to the most important controlled components of public health. Drinking water quality control is a priority for Governments around the world and should be regulated at the legislative level.

Pollution of water bodies - sources of drinking water supply with insufficient efficiency of running water treatment plants leads to deterioration of drinking water quality and public health in many regions of Ukraine, as proved by many researchers $[1,2]$.

One of the most pressing problems in the hygiene of water supply is the urgent need to review and improve regulations, state sanitary norms and regulations, standards and other regulatory instruments in the field of drinking water supply, including through the development of regional standards for the quality of drinking water [3].

SanRN 2. 2. 4-171-10 provide for the control of drinking water quality in seventy-six indicators, including physiological integrity, which include general mineralization, general stiffness, general alkalinity, iodine, potassium, calcium, magnesium, sodium and fluorides [3].

However, despite a fairly large amount of data in favor of introducing regional standards for the quality of drinking water, this issue is still open.

Magnesium ions are involved in the activities of enzymes, in particular carboxylases of living organisms. Calcium and magnesium, together with sodium and potassium, are essential elements of the vital activity of cells of living organisms. Calcium ions affect the activities of the nervous system, take part in the construction of the skeleton, metabolism, and also in the process of blood coagulation. A feature of the Ukrainian national system of sanitary and hygienic rationing of drinking 
water quality is the allocation of a separate group of indicators of the physiological integrity of drinking water that determines the adequacy of its mineral composition to the biological needs of the body. They are based on the appropriateness for a number of biogenic elements of considering not only the maximum permissible, but also the minimum necessary levels of their content in water. Indicators of physiological adequacy, as mentioned above, include general mineralization, total stiffness, total alkalinity, magnesium, calcium, potassium, sodium, iodine and fluorine $[1,3]$.

With the help of modern methods of analysis and study of the objective state of health of persons, drinking water of a certain salt composition is consumed for a long time, patterns of influence of salt components on the state of functional reserves of the adult body, dynamics of physical development of children and ranges of adaptation to mineral waters of a certain composition are established. When comparing the characteristics of drinking water of two water intakes of the city of Uzhhorod (1 - Minaisky water intake and 2 - Novodomaninsky water intake) and the Rakhivsky water utility established the following:

1. Regional features of the composition of drinking water of the mountain Rakhiv district of the Transcarpathian region are the high variety of combinations of mineral components and the frequent excess of the normative content of dry residue components, namely nitrates $(15.8 \mathrm{mg} / \mathrm{d} 3 ; 5.8$ $\mathrm{mg} / \mathrm{d} 3 ; 7.4 \mathrm{mg} / \mathrm{d} 3 ; \mathrm{p}<0,05)$; sulfates $(20.1 \mathrm{mg} / \mathrm{d} 3 ; 8.2 \mathrm{mg} /$ d3; $14.7 \mathrm{mg} / \mathrm{d} 3$; p <0,05); chlorides (31. 0 mg-eq. d3; 16.0 mg-eq. d3; 10.0 mg-eq. d3; p $<0,05)$; magnesium ( 2.0 mgeq. d3; 0.2 mg-eq. d3; 0.6 mg-eq. d3; $<<0,05)$; calcium ( 3 . 1 mg-eq. d3; 1.8 mg-eq. d3; 2.3 mg-eq. d3; p <0,05); and mercury $(<0.0005 \mathrm{mg}$-eq . / dm 3$)$. Water oxidation $(0.92$ $\mathrm{mg} \mathrm{O} 2 / \mathrm{dm} ; 1.4 \mathrm{mg} \mathrm{O} 2 / \mathrm{dm} ; 0.8 \mathrm{mg} \mathrm{O} 2 / \mathrm{dm} ; \mathrm{p}<0,05)$; total stiffness (5. 1 mg-eq. / d3, 2. 0 mg-eq. d3; 2.9 mg-eq. d3; $\mathrm{p}<0.05)$ and total alkalinity $(1.1 \mathrm{mg}$-eq . / d3; $1.1 \mathrm{mg}$-eq. d3, 3.0 mg-eq. d3; p <0,05).

2. Quotas of the water factor in the supply of vital macroand trace elements for the population of the mountain Rakhiv district of the Transcarpathian region, respectively, range from 3.7 to $26 \%$ for magnesium, from 1.1 to $21 \%$ for calcium, for sodium - from 0.04 to $10.0 \%$; 0.18 to $0.56 \%$ by potassium.

3. The established indicators of drinking water quality are directly dependent on the prevalence and intensity of dental caries in children, that is, a significant increase in the number of carious temporary teeth was diagnosed $(5.4 \pm 0.1 \mathrm{cu}$; 10. $1 \pm 0.1 \mathrm{cu} ; \mathrm{p}<0,05)$; carious permanent teeth $(2.3 \pm 0$. $1 \mathrm{cu} ; 5.6 \pm 0.1 \mathrm{cu} ; \mathrm{p}<0,05)$; removed permanent teeth ( 0 . $2 \pm 0.1 \mathrm{cu} ; 0.9 \pm 0.1 \mathrm{cu} ; \mathrm{p}<0.05)$ and reduction of filled temporary teeth $(7.5 \pm 0.2 \mathrm{dd} ; 4.8 \pm 0.1 \mathrm{cu}$.; $\mathrm{p}<0.05)$ and filled permanent teeth $(8.4 \pm 0.2 \mathrm{cu} ; 5.8 \pm 1.2 \mathrm{cu} ; \mathrm{p}<0,05)$.

\section{CONCLUSION}

The role of individual components of the salt composition of drinking water on the health of children and adults varies, in particular, the health of children is more influenced by the content of calcium and magnesium cations, as well as the content of nitrates and fluorine; whereas for adults, sodium content is more important, the value of stiffness that significantly affects the risk of dental pathology of hard dental tissues, doubling it.

Drinking water consumption of physiologically inadequate salt composition negatively affects the health of the child population. A reliable negative correlation of the mean force $(\mathrm{R}=(-0.35 ;-0.44), \mathrm{p}(\mathrm{R}=(-0.35 ;-0.44)$ was found.

One of the most pressing problems in water hygiene is the urgent need to review and improve regulations, State sanitary regulations, standards and other regulations in the field of drinking water, including through the development of regional drinking water quality standards.

\section{REFERENCES}

1. Perepelica 0.P. Ekohimia ta endoekologia elementiv [Ecochemistry and endoecology of elements]. Kyiv. 2004:736. (in Ukrainian).

2. Pro zatvergenia Dergavnih sanitarnih norm ta pravil «Gigienichny vimogi do vodi pitnoi, priznachenoi dla spojivannia ludinou» 2.2.4171- 10. - Nakaz Ministerstva ohoroni zdorovia Ukraina vid 12 travnia 2010 roku N 400. - Zareestrovano v Ministerstvi usticii Ukraina 1 lipnia 2010 roku N 452/17747. [0n approval of the State sanitary norms and rules «Hygienic requirements for drinking water intended for human consumption» - Order of the Ministry of Health of Ukraine of May 12, $2010 \mathrm{~N} 400$, Registered with the Ministry of Justice of Ukraine on July 1, $2010 \mathrm{~N}$ 452/17747]. (in Ukrainian).

3. Vorohta Yu.M. Gigienichna ocinka vplivu mineralnogo skladu pitnih vod na zdorovia naselennia: avtoref.dis..kand.med.nauk 14.02.01. Derjavna ustanova «Institut gigieni ta medichnoi ekologii 0.M.Marzeeva» AMN Ukraini [Hygienic assessment of the impact of mineral composition of drinking water on public health: Abstract. dis ... cand. honey. Science: 14.02.01. State Institution "Institute of Hygiene and Medical Ecology named after OM Marzeev" of the Academy of Medical Sciences of Ukraine.]. Kyiv. 2007:22. (in Ukrainian).

4. Klitinska O.V., Kostenko Y.Y., Gurando V.R. Determination of criteria early caries diagnostics in children of different ethnic groups domiciled in biogeochemical deficiency of fluorine and iodine. Journal of Stomatology. 2016; 70 (1), 1:51-6. D01: 10.5604/01.3001.0010.1778.

5. Kaskova L.F., Artyom's A.V. Prognozyvannya poshirenosti kariesy v istorichnomy aspekty. [Forecasting the breadth of carisu in the historical aspect]. Medical Medicine and Biology. 2012; 4: 26-8. (in Ukrainian).

6. Klitinska 0.V. Kompleksne obgryntyvannia diagnostiki, profilaktiki ta poetapnogo likyvannia kariesy y diteh, iaki postihno projivaut v ymovah bioheoximichnogo deficit ftory ta iodu [Complex diagnostics, prevention, and preventive care of children, as well as living in the minds of biologic deficiency of fluorine and iodine]. Poltava, 2015; 150-240. (in Ukrainian).

7. Klitinska 0.V., Vasko A.A., Mukhina Y.A. Exogenus drug prevention of dental caries in primery school children with high caries activity. Intermedical journal. 2016; 1 (7):10-12.

8. Klitinska 0.V., Kostenko Y.Y., Mukhina Y.A. et al. Efficiency estimation of using phased program of caries prevention in children domiciled in Transcarpathian region. Acta stomatologica Naissi. 2016; 32 (74): 1635-49. D0I: 10.5937/asnl674635K.

9. Klitinska O.V., Gasyuk N.V, Kostenko Y.Y. et al. Statistical model of caries formation and progression in children of preschool and early school age domiciled in biogeochemical deficiency of fluorine and iodine. Journal ofStomatology.2017;70(6),1:674-8. D0l: 10.5604/01.3001.0010.7725. 
10. Klitinska O.V., Vasko A.A., Borodach V.O. et al. Clinical and Laboratory Grounds for the Rational Selection of Filling Material for the Restoration of Deciduous Teeth. Pesquisa Brasileira em Odontopediatria e Clinica Integrada. 2018; 18(1): 3949 D0l:http://dx.doi.org/10.4034/ PBOCI.2018.181.52 ISSN 1519-0501.

11. Kiselnikova L.P., Smolar N.I.Terapevticheskaya stomatiligia detskogo vozpasta [Therapeutic dentistry of children]. Kyev: Book Plus. 2013; 64-85. (in Russian).

This work is a fragment of the research and development the Department of Paediatric Dentistry, State Higher Educational Establishment Uzhhorod National University "Comprehensive justification for providing dental care for children living in the area of biogeochemical deficiency of fluorine and iodine» (№ state registration 0119U101329).

\section{ORCID and contributionship:}

Oksana V. Klitynska: 0000-0001-9969-2833 ${ }^{A, F}$

Natalia V. Hasiuk: 0000-0002-6798-9090 ${ }^{\mathrm{C}}$

Volodymyr I. Struk: 0000-0002-1127-1485 ${ }^{B}$

Roksolana Yu. Kruchak: 0000-0002-9235-1662 ${ }^{E}$

Viacheslav R. Gurando : 0000-0001-6303-3799 D

Vasyl V. Bobelskyi: 0000-0002-4511-8489 C

\section{Conflict of interest:}

The Authors declare no conflict of interest.

\section{CORRESPONDING AUTHOR Oksana V. Klitynska \\ Uzhhorod National University \\ 3 Narodna Square, 88000 Uzhhorod, Ukraine \\ tel: +380312233341 \\ e-mail: klitinskaoksana@i.ua}

Received: 10.12 .2020

Accepted: 31.03 .2021

A - Work concept and design, B - Data collection and analysis, C - Responsibility for statistical analysis,

D-Writing the article, $\mathbf{E}$-Critical review, $\mathbf{F}$ - Final approval of the article 